\title{
ETHNIC POLITICS AND HEGEMONY: A HISTORICAL APPRAISAL OF COLONIAL AND POST COLONIAL NIGERIA
}

\author{
O. S. OSADOLA $(\mathrm{PhD} .)^{\mathbf{a}^{*}}$, S. A. OLUDEMI ${ }^{\mathrm{b}}$ \\ oluwaseun.osadola@fuoye.edu.ng \\ a. Department of History and International Studies, Federal University, Oye Ekiti, Ekiti State, Nigeria \\ b. Department of History and International Studies, Federal University, Oye Ekiti, Ekiti State, Nigeria
}

\begin{abstract}
Nigeria cannot be described as one homogeneous country for its differing peoples and ethnic groups. This fact raises the issues of ethnicity in Nigeria politics from 1960 up till date. With the heterogeneous nature of the country, the tendency of the various nationals is towards parochial consciousness at the expense of national consciousness. The three "hegemonic" ethnic groups constitute $57.8 \%$ of the country's population. All other ethnicities constitute different degrees of minority status. The dominance of the national population by the three majority groups was further enacted by the tripod regional administrative structure of the 1950 's which gave each majority ethnic group a region which forms the foremost context for ethnic mobilization and contestation. As a guide to answering the question on issues of ethnicity in Nigeria, this study documents the origin of ethnicity in Nigeria, ethnic politics in Nigeria before independence and ethnic hegemony in post-independence Nigeria as this played a major role in Nigeria politics over the years. This study employs secondary sources as well as thorough descriptive and analytic methods of report writing.
\end{abstract}

Published by IJRP.ORG. Selection and/or peer-review under responsibility of International Journal of Research Publications (IJRP.ORG)

Keywords: Ethnicity, Hegemony Ethnic Politics, Colonial rule, Post-colonial, Nigeria

\section{Introduction}

Before the amalgamation exercise of 1914, the entity now known as Nigeria had distinct autonomous and independent nations like the Yoruba, Hausa-Fulanis and the Igbos among others. (Lloyd, 1970: 13) Each of these groupings had different social, cultural, political and economic life styles different from one another. (Lloyd, 1970) The colonization of Nigeria brought about the amalgamation of these diverse groupings into a single geo-political entity now known as Nigeria.

At best, the 1914 amalgamation exercise embarked upon by Lord Luggard of the areas North and South was unification without unity or unity in diversity. Thus the activities of these diverse groupings constituting the contemporary Nigeria state have at different times in the political history of Nigeria resulted in strains and stress within the Nigeria federation. These strains and stresses have often resulted to serious threats to the stability of the corporate existence of the Nigerian state. Even the political economic and social activities within the Nigerian state are all anchored and propelled by the effect of ethnicity. In this connection, this paper will examine how ethnicity has affected Nigeria politics. It will explore how the various ethnic groups use the existing political parties to promote their ethnic interest before and after independence as well as the effect of their actions and inactions. (Ikime, 1980: 56) 


\section{Conceptual Review of Ethnicity}

Ethnicity has been defined by Nnoli, as a social phenomenon associated with interactions among members of different ethnic groups; it is behavioural in form and conflictual in content. (Nnoli, 1978: 6) He gave a working definition in the context of the Nigeria colonial experience. He opined that the concept of ethnicity applies to the consciousness of belonging to, identifying with, and being loyal to a social group distinguished by shared cultural traditions, a common language, in-groups sentiment and self identity.

From the above definitions, it can be deduced that ethnic groups have to come into contact before the phenomenon of ethnicity occurs. Ethnicity has been traced to colonial rule. It was during colonial rule that ethnic groups first acquired a common consciousness. But for colonial rule in Nigeria, It seems the various groups which constitute the present day Nigeria should have developed at their own pace. Thus the ethnic conflicts and squabble between and within the various groups in Nigeria and its attendant consequences for politics in the Nigeria political life should have been prevented. This view is supported by P.C. Lloyd who says;

Nigeria problems do derive in large measure from the tensions which have arisen between the larger ethnic groups and that the hostility derives.., not from the ethnic differences, but from competition between peoples for wealth and power. (Lloyd, 1970)

The above assertion becomes manifest in the light of the development of relations between the various ethnic groups during and after independence. Hence, it is imperative to assess the dimension of ethnic politics in both pre-independent and post-independent era of Nigeria's political development.

\section{Ethnic Politics in Nigeria before Independence}

The various ethnic groupings had existed before the creation of the Nigeria state in 1914 but ethnicity became politicized and its influence got heightened in the Nigeria political scene in the late 1930's. This followed the emergence of the Nigerian Youth Movement formed in 1934 as an opposition political party to the Macaulay's Nigerian National Democratic Party to contest election to the Lagos Town Council. (Idahosa, 2014)

The Nigerian Youth Movement ran into trouble over the replacement of Kofo Aboyomi who resigned his seat from the legislative council two members emerged for nomination Ernest Sessi Ikoli and Samuel Akinsanya. Azikiwe supported Akinsanya (Yoruba- ljebu) while Awolowo supported Ernest lkoli (Ijaw). The final decision according to the rule of the organization rested with the executive which decided in favour of Ikoli. Azikiwe resigned in annoyance and all the lgbo members of the organization resigned with him. This was a cause for suspicious to the non-Ibo members, who believed that though Azikiwe had supported a Yoruba, his support was not based on conviction but was dictated by the desire to split the organization in which he found his ambition somewhat thwarted. (Lloyd, 1970) As pointed out by Ikime, "the fact that all the lgbo members resigned with him give the other members food for thought". (Ikime, 1980) They reasoned that if the lgbo continued the policy of closing ranks on issues while others remained divided on grounds whether of principle or personality, it was only a question of time before the lgba dominated all the rest. This controversy left the party divided, thus leaving the party as an entirely Yoruba organization. The genesis of the political conflict between the lgbos and Yorubas which started in the 1930s, extended beyond Nigeria's independence. Thus this unhealthy ethnic rivalry between the lgbos and Yorubas was extended to publications in the newspapers football matches, among others. (Awolowo, 1947: 128) Matter got to a climax with the emergence of Awolowo as leader of the Egbe Omo Oduduwa which metamorphosed into the Action Group in the early 1950's and consequently the leader of the Yorubas. (Ojo, 2016: 76-80) 
It can also be said that Governor Bourdillon contributed to the forging of a North-South dichotomy but there is evidence that he wanted to encourage greater contact between North and South. His ideas found an outlet in the Richards constitution which was introduced in 1945. One of his objectives was to promote the unity "for the diverse elements which make up the country". One significant aspect of the constitution was the introduction of the concept of regionalism. It was a separatist attitude of the colonial administrators. This concept of regionalism, introduced by the Richard constitution was to undergo major changes deriving sustenance from the escalating strains of ethnic conflict. (Ezera, 1960: 70-84)

Ethnic rivalry prior to the 1950 General conference at Ibadan, which was preparatory to the birth of the Macpherson Constitution, was limited only to the Western and Eastern parts of Nigeria. Issues discussed at the General Conference brought the North into the main stream of ethnic antagonism in Nigeria. Some of the issues discussed included:

a) The size of the regional units in the Nigerian federation

b) Regional representation in the central legislature

c) Revenue allocation

d) Franchise and citizenship

e) Ministerial responsibility and the status of Lagos. (Greene, 1971)

Disagreement erupted between the Northern and Southern representatives, at the conference on some issues- some of the issues included:

a) Northern representatives wanted 50 percent representation at the central legislature.

b) Per capita division tax revenue. (Greene, 1971:23)

To these demands, the Eastern and Western delegates at the conference objected. The Northern delegates at the conference objected to the demand for cabinet responsibility both at the centre and regional levels. Disagreements also aroused in matters concerning change in the hitherto existing regional boundaries. (Albert, 1998: 50) On this issue the Northern delegates had their way. But on the issue of Northerners given half of the seats of the central legislature, the Emirs of Kastina and Zaria threatened that unless their demands were met they would opt for separation based on the former arrangement prior to 1914. (Okwudibia, 1995: 121) Kirt Greene remarked that the decision to allow the North claim was one that was to dominate the shaping of Nigeria's political culture until the first republic exploded thirteen years later. (Greene, 1971)

The ethnic bases of the three major political parties helped to worsen the relationship between the major political parties in Nigeria prior to independence and beyond with the inception of the Macpherson institution in 1951, there came to exist three major political parties. These parties were the National council for Nigeria citizen (NCNC) the Action Group (AG) and the Northern Peoples' Congress (NPC). Each of these parties had their strengths and backings from their own ethnic groups. Thus the $\mathrm{NCNC}$ had their stronghold in the East, the AG in the West and the NPC in the Northern region Awolowo led the AG in the Western region, Ahrnadu Be led the NPC in the Northern region. Azikiwe who though the leader of the NCNC resided in Lagos and became a member of the Western House of Assembly for that constituency. None of the above leaders of the political parties was in the council of ministers at the centre. (Ikime, 1980) 
Matters got to a head, when Azikiwe who wanted to enter the House of Representatives got defeated in view of the constitutional requirement which specified conditions for membership of the House of Representatives. This coupled with the ethnic and party rivalry, made Azikiwe's effort abortive. (Nnoli, 1994) The 1951 constitution made selection of membership of the house of representative a function of the regional legislature. This procedure for selection of representatives gave the majority party, the AG the powers to select from within the Western Regional House of Assembly, representatives in the central legislature at Lagos. The AG had the power to dictate who was to represent the region in the House of representative at Lagos. This power, the AG used effectively, thereby preventing Azikiwe from being a member of the House of representative; since members selected were all from Yoruba origin. (Lloyd, 1970) No other explanation could be used to describe the above situation than ethnicity at play

The above situation helped to fan the ember of ethnic rivalry in Nigeria politics. Hence ethnicity was politicized, Kalu Ezera Sums up the situation that:

Azikiwe was defeated in the bid to go to the House of Representatives because he was an Ibo. Since his party colleagues who were selected were all Yorubas. The consequence of the incidence was the resignation of Zik from the Western house and moved to the eastern region. (Ezera, 1960)

The 1951 constitution was generally an improvement on the 1946 constitution but its ethnic connotation posed regional divisions. The competitive interests of the ethnic groups worked against the constitution's longetivity.

Tension and fear of domination between the three dominant ethnic groups in Nigeria were blown out of proportion when on the 31 of March 1953, Anthony Enahoro, an Action Group member of the House of representative moved a motion for self-government for Nigeria in 1956. The Northerners saw the motion as an attack against the Northern interest and an attempt for the Southerners to dominate them. (Nnoli, 1995) On the grounds of unpreparedness for 1956 as the year of independence, the Northerners in the House of Representatives rejected the motion. The leader of the NPC Sir Ahmadu Bello moved a motion for an amendment to the effect that the phrase" as soon as practicable" (Idahosa, 2014) should replace the date of 1956. To him, the North was not ready for independence and should not be hurried. His views were rejected by the southern members of the House and thus, a sharp division arose between the south and the North. This led to the walk out of Western and Eastern members from the house of representative and the four ministers from the south resigning their portfolios in the central executive. The Northern legislators were jeered at and called names by Lagosians. The incidence convinced the North that it could not walk with the south. The North therefore put forward an eight point programme, which if implemented would have meant the breaking up of the country. A cause they were persuaded to drop by the colonial administrators. (Sklar, 1963) The eight points wanted a complete executive and legislative autonomy for the North, except in defense, external affairs, customs and research institution. Among other demands were

- All revenue except customs should be levied and collected by regions

- A central agency which is non-political with no legislative or policy making powers Lagos the capital should be a neutral zone. (Nwosu, 1999)

Events happened in quick succession and situation got out of control when in May 1953, the AG and NCNC sent a delegation under Chief S.L Akintoa to assess the views of the Northerners vis a vis NPC delegates view in the House of representatives as regards the independent for Nigeria in t956. The aftermath of this tour to the Northern region resulted in the Kano riot of May $16^{\text {th }}$, 1953. In which about thirty six people were killed and two hundred and fifty people were wounded. This was a clear manifestation of the ethnic conflict in the Nigeria political scene prior to independence and it worsened the relationship between the North and the South. (Ojo, 2016) 
Between the 1950's and 1960's the fears of the Northern of Southern domination increased rapidly. And to achieve the much desired autonomy, the Northerners began an aggressive Northernisation policy as a result of which many southerners lost their job in the Northern public service and encouraged to seek employment in the south where they belong. By 1958, there were five Northerners in the top echelon of the service, sixty nine in the administrative and professional cadre and 237 in the executive and higher technical cadre. Southerners were edged out. (Ottawa, 1999) The only credentials for getting employed in Northern establishments were to be member of the N.P.C. On the extent of the Northernisation policy, Sir Almadu Bello said.

The Northernisation policies do not only apply to clerks' administrative offices, doctors and others. We do not want to go to Chad and meet strangers catching our fish in the water... we do not want to go to Sokoto and find a carpenter who is a stranger nailing our houses. do not want to go to the Sabon Gari Kano and find strangers making the body of a lorry, or to go to the market and see butchers who are Northerners. (Oyediran, 2000)

The Northernisation policy alienated the southerners and even the Ibo speaking people among them. This policy further heightened ethnic politics in Nigeria.

\section{Post Independence Nigeria}

Ethnic rivalry between North and South got to its height in the event which followed the country's independence. The elections of 1959 were crucial for the political parties as they were to determine who would control the federal government at independence. The NPC won all 174 seats allocated to the North; it means it could control the 312 member House of representative. For this reason, it became part of the strategy of the NCNC and the AG to stop the NPC from winning all the Northern seats. They did this by entering into alliances with smaller Northern parties. But none of the parties had a working majority. (Ikelegbe, 1988: 10) The NCNC and the AG together had 162 seats, enough to form a government. Given the fear of Northern domination, one would have taught that an NCNC-AG coalition would emerge. But it did not instead; it was an NPC-NCNC coalition that emerged, even though there was really nothing of an ideological nature that bound these two parties together, self-interest was the determining factor. (Nwachukwu and Osadola, 2019) The NCNC which had a fair showing in the West, hoped that once in government, it could improve its standing in future elections and probably take over the government of the West. If it did that, it would have control of the south and this would strengthen its negotiation with the North. In the meantime, it would use partnership in the federal government to secure resources for the Eastern region. The NPC on its part, resented the anti-Northern utterances of the AG and its leader, Obafimi Awolowo, and so would not go into alliance with AG. (Amadu, 1999) In a sense, the NCNC reaped dividends from its decision, its leader Dr. Nnamdi Azikiwe became the first president of the senate then Governor General, then the first president of the federal republic of Nigeria. (Akamere, 2005) Party members become ministers and enjoyed other patronage.

In May 1962, a nationwide population census was conducted in Nigeria but there was an atmosphere of suspicious over the exercise. And on May 13, 1963, a fresh census was conducted but it was not without its controversies.' The final figures showed that the population of the Northern region alone was more than that of the other regions including Lagos combined as a result, political observers saw that this would entitle the North to more electoral constituencies than the rest region. The premier of the Eastern region, mid-western region, as well as the AG rejected the figure on the ground that the figures credited to the North were highly inflated. But the federal government accepted the figures. The political implications of the census discrepancy were the series of politic realignment that preceded the federal election that year. The election was marred by fraud and electoral malpractice and this greatly disillusioned and eliminated both East and West and made the Ibos felt powerless as the result was accepted by the NPC led Alliance. (Nwachukwu and Osadola, 2019) 
The fears of the lbos and feelings were brought to the boiling point in 1965 over the election crisis in the Western House of Assembly. Unlike the federal election of 1964, the outcome of the 1965 election had no doubt as far as the electorate was concerned. The unpopular government of Akintola had no chance of receiving a majority vote inspite of violence, fraud and the other machinations of the NPC and its regional ally the NNDP, the NCNC and its ally the AG were confident to victory. This confident turned into disillusionment, frustration, alienation and violence when the results gave victory to the NNDP. Anarchy let loosed in the region. The fast was finally convinced that arrogance, political imprudence and political greed of the Hausa Fulani could not be overcome within the context of a united began to consider breaking up the country. This was the state of affairs when the coup of January 1966 took place. (Idahosa, 2000)

\subsection{Ethnicity in the Context of "1966 Coup"}

In all cases of analyses, the coup presents itself as ethnic in character. (Muffet, 1982) The prime minister of the Eastern Region and that of the Midwest who were Ibos were not killed. The bulk of the senior military officers killed were of Northern origin. Among the civilians killed none were lgbo. They included the premier of the North, Ahamedu Bello, the controversial and hated premier of the West S. L. Akintola and the Federal Prime Minister Abubaka Tafewa. No harm came to Michael Okpara nor O.C. Osedebe, the lgbo premier of the East and Midwest respectively. Within the military, four out of five northern officers of the ranks of lieutenant colonel and above were killed, two out of five from the West, none from the East and one from the Midwest. The only survival officer within that rank from the North is Col. Yakuba Gowon. As pointed out by Muffett,

the killing of the four officers in Lagos can only be explained in terms of deliberate elimination ...... All were Northern...., the Ibo who was to die at the hands of the plotter was Lieutenant Colonel A.G. Unegbu the quartermaster-General of the army headquarters in Lagos and he was murdered because being in charge of the armory he had refused to hand over the keys to the plotters when they are awake in the early hours of $15^{\text {th }}$. (Muffet, 1982: 32)

Six of the seven majors and nineteen out of the other twenty three persons who participated actively in plotting and executing the coup came from the same ethnic group the lgbo. The military coup had the effect of replacing a federal government headed by a Northerner with one headed by an Ibo. According to Obaro Ikime, "had the gun achieved for the lbos what politics and the ballot box could not?" (Ikime, 2006: 297) The coup led to the demise of the first republic (1963-1966).

From independence to January 1966, the country had been in a serious ethnic turmoil but the coup placed her in an uneven greater situation. The Northerners saw the coup as a deliberate plan to eliminate the political heavy weight in the North in other to pave way for the Easterners to take over the baton of leadership.

The North wanted to reassert itself as Muffet pointed out

...the old song of Ibo domination is recklessly driven home with increasing venom.., the north is beginning to speak out and language does not make good music to the ears.... (Muffet, 1982)

And so the north hoped to reassert itself which it did in July 1966 known as the counter coup, which latter led to the 30 months civil war on 30 May 1967. It can be shown from the short post-colonial history of Nigeria (1960-1967) that ethnic pressures and demands have resulted in tensions and conflict that threatened it political 
order. The 1979 constitution which entrenched the federal character principle extended it to political parties insisting that each political association must establish in 13 of the 19 states its leadership reflecting the geographical diversity of the country arid that ethnic connotations must be absent from their emblems before they are registered as political parties. But after the 1979 elections, the results of the elections did not only show the predominance of personalities but also the importance of their ethnic origin. Therefore, my summation is that the ethnic factor which had its roots in colonial era remained the Achilles heel of post-colonial Nigeria up to 1979. (Ikelegbe, 2004)

\section{Implications of Ethnicity on Nigeria's Political Development}

Nigeria has been characterized by perpetuating socio political instability right from the three years of independence. This is consequent upon Nigeria's ethnic multiplicity and its associated political oddities. There are crises here and there that cause political instability in the country. Incidences of communal clashes between ethnic groups have been on the increase even in recent years. In real terms Nigeria has never really been an integrated nation, most of the time what is described as harmonious co-existence between groups is often very fragile and this snaps as soon as there is any slight provocation what follows after wards are violent clashes in which lives are lost, for example the Warri ethnic war of 1997. (Otite, 1999) Another major effect of ethnicity in Nigeria is lack of accountability in governance as ethnic leader fan embers of ethnic competition to conceal the lack of commitment to good governance and the democratic process. (Soetan and Osadola, 2018)

There is also massive public corruption at all levels in the quest for personal and ethnic economic power and influence which leads to electoral malpractices to keep the ruling ethnic group in power at all cost couple with the use of state sponsored force to keep a ruling ethnic good in power regardless of its unpopularity. (Maitama-Sule, 2000) Since 1999, when the military finally stepped down from power, following massive public opposition to military rule there has been a resurgence of ethnic politics and competition for power in Nigeria. (Nwachukwu and Osadola, 2019)

\section{Conclusion}

The issue of ethnicity has plagued the Nigerian political scene with its setting occasioned by the arbitrary amalgamation of groups with different social, cultural and historical background being lumped into a geopolitical entity via British fiat and its effect was unity in diversity. Its effect created crises on the political system in preindependent and post independent Nigeria. Thus ethnicity was politicized with each of the dominant ethnic groups competing for wealth and power within the Nigeria state. The fight for independent also was moulded along ethnic lines the goal of each was the emergence of a Nigeria moulded after its image, controlled by it or at least the control of which it was not excluded from there was therefore division, hatred, unhealthy rivalry and pronounced disparity in development.

At independence, ethnic consciousness increased and manifested itself in the political scene of the country. Ethnic disparity also led to the avalanche of political crisis which crissed- crossed the country between 1960-1966. These events culminated in the coup and counter coup of 1966 which led to the thirty months bloody civil war in 1967. The war was not without ethnic consciousness the lbos in the various regions supported the course and the war effort. The Ibos poured in large numbers to fight a war whose course was to be free from punishment imposed on them. Ibos in other regions of the country, especially those in the mid-western regions paved the way and prepared grounds for their fellows to come in, in a bid of fostering their plight. (Idonoje and Ehizuelen, 1996) The mid westerns saw the Biafra's as invaders and therefore supported the federal government course of keeping one Nigeria. The west also supported the federal government as Awolowo was placated by the federal government the war ended in 1970 when Maj. Gen. Effiog announced the surrender of the Biafra people on Radio Biafra and surrendered to Brigadier Olusegun Obasajo. The 1979 constitution although introduced the federal character and extended it to 
political parties, ethnic disparity still influence Nigeria scene. By way of a concluding statement, the politics of preindependent and post independent Nigeria up to 1979 was not without ethnic connotations.

\section{REFERENCES}

Akamere, F. A. C., (2005) Issues and concepts in Government and politics of Nigeria, (Lagos: Olu - Abbey Modern press,), p. 156-157.

Albert, O., (1998) Federalism, Inter-ethnic Conflicts and the Northernisation policy of the 1950s and 1960s in Federalism and political

Restructuring in Nigeria Edited by Kunle Amuwa et al (Ibadan, Spectrum Books limited,), p. 50.

Amadu, K.,. (2000) The Nigerian General Elections, 1959 and 1979 and the aftermath, Lagos Macmillan, p. 34

Awolowo, O., (1947) Path to Nigeria freedom, (London, University press,), pp 124-134.

Boahen, Webster, (1979) The Revolutionary years; West Africa since 1800.

Dudley, B., (1973) Instability and Political Order. Ibadan: Ibadan University Press,

Ezera, K. Constitutional Development in Nigeria (London, Cambridge University press, 1960), pp. 70-84

Greene, A. H. M K, (1971) Crisis and conflict in Nigeria: A Documentary source book 1966- 1970. (London, University press,), pp. 1-24.

Idahosa, S. A. and A. E. Ehizuelen (1996) Readings in politics and Administration., Silva Publication Limited p. 118

Idonoje, A.D. and Ehizuelen, A.E., (1996) Political Behaviour. The case of ethnic and sectional Tension in the Nigerian political formation in readings in politics and Administration (Akure, Ondo state: Sylva publications Ltd)., P. 116.

Ikelegbe, A.,. (1988) Post Colonial Nigerian Government and Politics: First Republic and Military Regimes. In: A. G. Onokerhorage (ed) An Introduction to Integrated Social Science for Africa, Benin City: Geography and Planning Series, p. 10

Ikime, O. (1980) Ground work on Nigerian History (Ibadan Heinemann Educational Books (Nig) Ltd), p. 56.

Ikime, O., (2006) History, the Historian and the Nation, lbadan, Olusey press Ltd), p. 297.

Lloyd, P.C.. (1970) The Ethnic Background to the Nigeria Civil war in S.K. Panter Brick (ed), Nigeria politics and military rule: prelude to civil war (London university press pp. 1-13)

Maier K.., This House Has Fallen: Nigeria in Crisis. London: Penguin Books, 2000,

Maitama-Sule, Y.. (2000), Ethnic Conflicts: When Tribes and Tongue Differ in Ethnic Conflicts - Counting the Human Cost. News Africa (UK) Limited,

Muffet, D. J., (1982) Let Truth Be Told: The Coups d' etat of nineteen sixty six, Haduhuda publishing company), pp. 39-40

Nnoli, O., (1978) Ethnic Politics in Nigeria. Enugu: Fourth Dimension Publishers,

Nnoli, O., (1994) Ethnicity and Democracy in Africa- Intervening Variables. Lagos: Nigeria: Malthouse Press Limited,

Nnoli, O., (1995) Ethnicity and Development in Nigeria. Aldershot: Avebury Publisher.

Nwachukwu J. U. \& Osadola, O. S.., (2019) Nexus between Elections, Good Governance and Democracy in Nigeria: 1922-1979, Global Scientific Journal, Vol. 7, Issue 5,

Nwosu, I. N., (1999) Nigeria in the Management of sub- Regional Conflicts, in A. Sanusi (ed.) Selected Themes in Nigeria Foreign Policy and International Relations. Ilorin: Sally and Associates,

Ojo, E. O, (2016) The Awolowo-Akintola Leadership Tussle: A Reinterpretation. Journal of Arts \& Humanities, Vol. 5, No. 1, pp 76-80

Okwudibia, N., (1995) Ethnicity and development in Nigeria, (Ashgate publishing Limited, p. 121.

Otite, O.,. (1999) On Conflicts, their Resolution, Transformation, and Managements, In : Otite, O. and Alberts, I. O. (eds.) Community Conflicts in Nigeria, Management Resolution and Transformation. Ibadan, Nigeria: Spectrum Books,

Ottawa M., (1999) Ethnic Politics in Africa: Change and Continuity, In Joseph, R. (eds.) State, Conflict and Democracy in Africa. London: Boulder Lynne,

Oyediran, D., (2000) Nigeria Government and Politics under military rule 1966-1979. P.9

Sklar, R. L., Nigerian Political Parties. Princeton, New Jersey: Princeton University Press, 1963

Soetan, S. O., and Osadola, O. S., (2018) Debt Burden: A Re-Examination of its Effects on Nigeria's Nation Building. Journal for Studies in Management and Planning ISSN: 2395-0463 Volume 04 Issue 01, pp. 43-50 